\author{
Z.A. Yestemessov ${ }^{1}$, Y.A. Auezova ${ }^{2}$, A.U. Uralkhanova ${ }^{1}$, \\ D.R. Ibraimov ${ }^{3}$, D.S. Odintsov ${ }^{1}$, A.M. Khaidarov ${ }^{1}$ \\ $\left({ }^{1}\right.$ TseLSIM LLP, ${ }^{2}$ Kazakh National University n.a. Al-Farabi, \\ ${ }^{3}$ Almaty Bridge Construction Plant LLP, Almaty, Republic of Kazakhstan)
}

\title{
CONSTRUCTION AND TECHNICAL PROPERTIES OF PC 500 DO CEMENT
}

\begin{abstract}
Annotation. It is established that physical and mechanical properties of Portland cement, including setting time and strength, correspond to mark PC 500 DO and meet technical requirements of the corresponding standard. However, they have increased dispersion ability and water consumption. It has been determined that the main Portland cement clinker minerals $\left(C_{3} S, \beta-C_{2} S, C_{3} A\right.$ and $\left.C_{4} A F\right)$ in cement are represented as solid solutions as a result of the presence of impurities in their structure.
\end{abstract}

Key words: cement, physical and mechanical properties, phase composition, cement stone.

Introduction. Concretes, in which cement is the main and determining component, are the second most used by people for their needs after water. At present time concretes with strength of $50 \ldots 70 \mathrm{MPa}$ are used in construction, and in ten years it (strength) can exceed $150 \ldots 300 \mathrm{MPa}$. Production of such ultra strong concretes is inextricably linked with the in-depth study of hydration processes occurring in the hardening and hardened cement stone. Therefore, the study of hydration and hardening of Portland cement PT 500 D0, which currently has the highest strength, has scientific and practical value.

Research methodology. Determination of normal density and setting time of cement PC 500 D0 was carried out according to GOST 310.3-76: Cements. Methods of determination of normal density, setting time and uniformity of volume changes. Tests were conducted with Portland cement PC 500 D0, corresponding to the physical and mechanical indicators of GOST 10178-85: «Portland cement and slag Portland cement. Technical specifications».

To determine the normal density, a sample of $400 \mathrm{~g}$ of cement was taken, dried to a constant mass and sieved through sieve No.09. In the selected sample of cement water necessary to obtain a cement consistency test was poured, at which immersed in a ring filled with dough, pestle of Vika device does not reach 5-7 $\mathrm{mm}$ to the plate on which the ring is installed.

The pestle of Vika device is replaced by a needle to determine the setting time of the cement test. The needle is immersed every 10 minutes in the ready-made cement dough until it sets. The setting of the cement dough starts from the beginning of the water pouring until the needle reaches the plate by $2-4 \mathrm{~mm}$, and the end of the setting is the time from the beginning of the water pouring until the needle is $1-2 \mathrm{~mm}$ immersed in the dough.

To determine the grade (strength) of cement according to GOST 4-81 prepare a mixture consisting of cement and monomeral quartz sand at a ratio of 1:3. Solution 
preparation is carried out according to GOST 30744-2001. The prepared mixture with the given mobility is placed in the form of $4 \times 4 \times 16 \mathrm{~cm}$., vibrate on a vibrating platform during 3 minutes. After a day, the samples are taken out of the mold, which are stored in humid conditions for 28 days, and then tested for bending and compression strength.

Samples prepared for steaming are placed in the chamber, where they undergo hydrothermal treatment at $85^{\circ} \mathrm{C}$ at $3+6+3 \mathrm{~h}$.

Chemical analysis of the sample (cement) was carried out according to the requirements of GOST 5382-91, according to which its oxide composition was determined.

X-ray phase analysis was performed on the upgraded DRON-3M diffractometer on $\mathrm{CuK} \alpha$ radiation with software. $\mathrm{X}$-ray diagrams of the sample were obtained in the imaging interval $2 \theta$ (angles) from 10 to $70^{\circ}$, step -0.050 , speed $-2 \mathrm{~g} / \mathrm{min}$, maximum intensity - $560 \mathrm{imp} / \mathrm{sec}$.

Results and discussion. Portland cement PC 500 D0 (hereinafter referred to as cement) consists of Portland cement clinker (94.25\%) and double-water gypsum (5.75 $\%)$, so it is very convenient to study its hydration hardening.

Tables 1 and 2 show the oxide composition of cement. The analysis of their data shows that:

- Its oxide composition generally meets the technical and technological requirements for raw materials in the production of Portland cement clinker [1, p.5];

- content of responsible oxides ( $\mathrm{MgO}, \mathrm{SO} 3, \mathrm{R} 2 \mathrm{O}$ and $\mathrm{C} 3 \mathrm{~A})$ to which the requirements comply with GOST 10178-85. However, there are still important technical requirements, not included in the normative documents. This is the ratio between the oxides, compliance with which contributes to the improvement of technological processes of Portland cement clinker production and increase the reliability of cements based on it. For example:

-It is considered optimal when the ratio of $\mathrm{SiO} 2 / \mathrm{A} 12 \mathrm{O} 3$ should be within the limits of 3.5...3.8, but not higher than 4.0, contributing to obtaining cement with high strength properties [1, p. 9]; in our case, this ratio of 22.4/4.47 is 5, which is a violation;

- traditionally, the content of $\mathrm{Al} 2 \mathrm{O} 3$ in clinker should be higher than $\mathrm{Fe} 2 \mathrm{O} 3$, and in our case the content of iron oxide is higher $(5.08 \%)$ than aluminum oxide $(4.47 \%)$, which contributes to the formation of a liquid phase of reduced viscosity, which in turn leads to the formation of clinker granules with unsatisfactory properties and to an increase in clinker dusting [1, p. 159];

- According to calculations based on the results of chemical analysis, the quantitative and qualitative content of clinker minerals in cement is, \%: $\mathrm{C} 3 \mathrm{~S}-48.7$; $\beta$-C2S - 27.54; $\mathrm{C} 3 \mathrm{~A}-3.11$; $\mathrm{C} 4 \mathrm{AF}-15.4$; in addition, the sample contains, \%: CaSO4-2H2O $-5.75 \%$ and $\mathrm{R} 2 \mathrm{O}$ (in terms of $\mathrm{Na} 2 \mathrm{O}$ ) -0.51 . It should be noted that for high-strength cements the $\mathrm{C} 3 \mathrm{~S}$ content in clinker should be higher than $55 \%$, and in this cement only 48.7\%; therefore, the increased activity of the studied cement PC 500 D0 is obtained by increasing its dispersibility; in addition, in terms of phase composition clinker is more suitable for sulfate resistant cement CEM I CC 42,5 H;

-normal density (ND) and setting time of the cement test, tested in accordance with GOST 310.3-76, meet the regulatory requirements and have the following actual 
value: ND - 30.0\%; setting start - 3 h $00 \mathrm{~min}$, the end - $4 \mathrm{~h} 10 \mathrm{~min}$; here we note: due to high dispersion cement has a high water demand and final setting; high water demand of cement can reduce the frost resistance of concrete based on it.

Table 1 - Chemical oxide composition of cement grade PC 500 D0

\begin{tabular}{|c|c|c|c|c|c|c|c|c|c|c|c|c|c|c|}
\hline $\mathrm{Na}_{2} \mathrm{O}$ & $\mathrm{MgO}$ & $\mathrm{Al}_{2} \mathrm{O}_{3}$ & $\mathrm{SiO}_{2}$ & $\mathrm{P}_{2} \mathrm{O}_{5}$ & $\mathrm{~K}_{2} \mathrm{O}$ & $\mathrm{CaO}$ & $\mathrm{TiO}_{2}$ & $\mathrm{MnO}$ & $\mathrm{Fe}_{2} \mathrm{O}_{3}$ & $\mathrm{SO}_{3}$ & $\begin{array}{c}\text { loss on } \\
\text { ignition }\end{array}$ & amount & $\mathrm{HO}^{2}$ & $\mathrm{Cl}^{-}$ \\
\hline 0,23 & 0,48 & 4,47 & 22,4 & 0,03 & 0,42 & 62,92 & 0,01 & 0,11 & 5,08 & 2,7 & 1,06 & 100,00 & 1,41 & 0,038 \\
\hline
\end{tabular}

Table 2 - Content of responsible oxides and $\mathrm{C}_{3} \mathrm{~A}$ in cement in comparison with technical requirements of GOST 10178-85

\begin{tabular}{|c|l|c|c|c|}
\hline No & \multicolumn{1}{|c|}{ Indicator name } & RD designation & $\begin{array}{c}\text { Norm } \\
\text { accordin } \\
\text { g to RD }\end{array}$ & $\begin{array}{c}\text { Actual } \\
\text { value }\end{array}$ \\
\hline 1 & $\begin{array}{l}\text { Content of tricalcium aluminate }\left(\mathrm{C}_{3} \mathrm{~A}\right), \text { not more } \\
\text { than }\end{array}$ & GOST 10178-85 & 8,0 & 3,11 \\
\hline 2 & $\begin{array}{l}\text { Content of magnesium oxide }(\mathrm{MgO}), \text { not more } \\
\text { than }\end{array}$ & GOST 10178-85 & 5,0 & 0,48 \\
\hline 3 & $\begin{array}{l}\text { Mass fraction of sulfuric acid anhydrite }(\mathrm{SO} 3): \\
- \text { not less than } \\
- \text { not more than }\end{array}$ & GOST 10178-85 & 1,0 & 2,7 \\
\hline 4 & $\begin{array}{l}\text { Mass fraction of alkaline oxides }\left(\mathrm{Na}_{2} \mathrm{O} \text { and }\right. \\
\left.\mathrm{K}_{2} \mathrm{O}\right) \\
\text { converted to } \mathrm{Na} 2 \mathrm{O}\end{array}$ & GOST 10178-85 & $*, 51$ \\
\hline $\begin{array}{l}\text { The } \\
\text { mass fraction of alkali metals in cement using a reactive aggregate is set as agreed with the }\end{array}$ \\
\hline
\end{tabular}

- The specific surface was about $450 \mathrm{~m}^{2} / \mathrm{kg}$ (the residue on sieve No. 008 was $1.0 \%$ ), the bulk density was $1140 \mathrm{~kg} / \mathrm{m}^{3}$, and the true density was $3.15 \mathrm{~g} / \mathrm{cm}^{3}$, the specific efficiency of natural radionuclides was $80.0 \mathrm{~Bq} / \mathrm{kg}$ (according to GOST 3010894 it should be below $370 \mathrm{~Bq} / \mathrm{kg}$ (Table 3)).

Table 3 - Physical and mechanical properties of cement PC 500 D0

\begin{tabular}{|c|c|c|c|c|c|}
\hline No & $\begin{array}{l}\text { Indicator name, unit } \\
\text { of measurement }\end{array}$ & $\begin{array}{l}\text { RD Designation } \\
\text { on the test } \\
\text { methods }\end{array}$ & $\begin{array}{l}\text { Norm according } \\
\text { to RD }\end{array}$ & $\begin{array}{l}\text { Actual } \\
\text { value }\end{array}$ & Note \\
\hline 1 & 2 & 3 & 4 & 5 & 6 \\
\hline 1 & $\begin{array}{l}\text { The remainder on sieve number } \\
008 \%\end{array}$ & GOST 310.2-76 & not more than 15 & 1,0 & \\
\hline 2 & $\begin{array}{l}\text { Normal density of cement dough, } \\
\%\end{array}$ & GOST 310.3-76 & not norm. & 30,0 & \\
\hline 3 & $\begin{array}{l}\text { The timing of the setting, hour- } \\
\text { minute: } \\
\text { start } \\
\text { end }\end{array}$ & GOST 310.3-76 & $\begin{array}{c}\text { not earlier than } 00-45 \\
\text { not later than } 10-00\end{array}$ & $\begin{array}{l}3-00 \\
4-10\end{array}$ & \\
\hline 4 & $\begin{array}{l}\text { Volume uniformity (expansion), } \\
\text { mm, not more than }\end{array}$ & GOST 310.3-76 & 10 & complies & \\
\hline
\end{tabular}




\begin{tabular}{|c|c|c|c|c|c|}
\hline 1 & 2 & 3 & 4 & 5 & 6 \\
\hline 5 & $\begin{array}{l}\text { Compressive strength after steam- } \\
\text { ing, } \\
\mathrm{MPa}\end{array}$ & GOST 310.4-81 & More than 32 & $\begin{array}{c}34,1 \\
\text { (Steaming } \\
\text { efficiency } \\
\text { group I } \\
\text { for PC } \\
500 \text { ) }\end{array}$ & \\
\hline 6 & $\begin{array}{l}\text { Strength at the age of } 28 \text { days, } \\
\text { MPa, at: } \\
\text { bending } \\
\text { compression }\end{array}$ & GOST 310.4-81 & $\begin{array}{c}5,9 \\
49,0\end{array}$ & $\begin{array}{c}7,4 \\
54,1\end{array}$ & \\
\hline 7 & True density, $\mathrm{g} / \mathrm{cm} 3$ & GOST 310.2-76 & not norm. & 3,15 & \\
\hline 8 & Bulk density, kg/m3 & - & not norm. & 1140 & \\
\hline 9 & $\begin{array}{l}\text { Specific effective activity of natu- } \\
\text { ral radionuclides, } \mathrm{Bq} / \mathrm{kg}\end{array}$ & GOST 30108-94 & up to 370 & 80,0 & \\
\hline 10 & Degree of hydration, $\%$ & & alized - $22 \%$ & ight & \\
\hline
\end{tabular}

This data indicates that:

- This cement is obtained from clinker designed for CEM I CC 42,5 by increasing its specific surface (to compensate for the lack of C3S content);

- increased true density indicates the clinker content of cement in the range of $95 . . .96 \%$ by weight, and its lower bulk density indicates increased dispersibility.

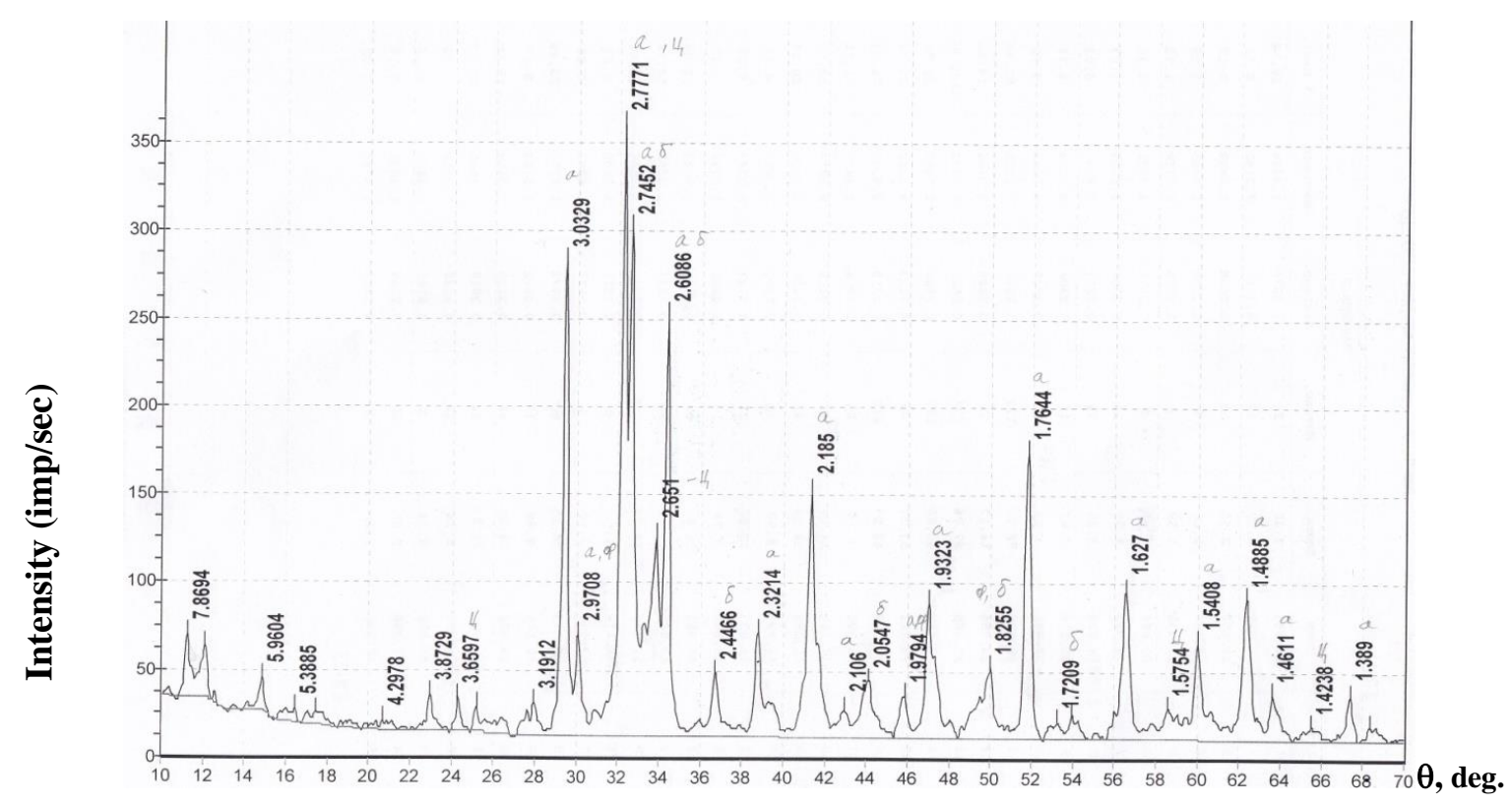

Figure 1 - Cement grade 500 D0

X-ray phase analysis of cement is shown in Fig. 1 and Table 4, which shows that:

- The radiograph captures the presence of alite $(\mathrm{C} 3 \mathrm{~S})$, belite $(\beta-\mathrm{C} 2 \mathrm{~S})$ and celite $(\mathrm{C} 4 \mathrm{AF})$, and no peaks typical for phyllite $(\mathrm{C} 3 \mathrm{~A})$ due to its low content in cement $(3.11 \%)$;

- Alite (C3S-54SaO-16SiO2-Al2O3-MgO) is the dominant phase, so its peaks on the radiography overlap the peaks of the other phases; 
- as expected, these minerals in the clinker composition do not appear in pure form, but as a solid solution, so the value of their peaks on the X-ray differs slightly towards small and large numbers; for example, pure alite and its solid solution in cement on the X-ray have the following corresponding peaks with interplane distances $\mathrm{d}, \AA$ : 3,034 (standard) - 3,029 (solid solution); 2,9728 - 2,9708; 2,7761 - 2,7771; 2,748 $-2,7452$, etc.;

-the peaks of solid solutions of alite, belite and celite on the radiograph are fixed with increased intensity and sharp; this indicates that the impurities that are part of the structure of these minerals contribute to improving the habitus of their crystals.

Table 4 - Diffraction characteristics of pure monominerals (before the line) [2] and in the cement composition PC 500 D0 (after the line)

\begin{tabular}{|c|c|c|c|c|c|}
\hline $\begin{array}{l}\text { Inter-plane } \\
\text { distances (d, } \\
\AA \text { A): in stand- } \\
\text { ard/in-cement }\end{array}$ & $\begin{array}{c}\text { Intensity: } \\
\text { as a peak in the } \\
\text { standard and as an } \\
\text { imp/sec in cement }\end{array}$ & $\begin{array}{c}\text { The symbol } \\
\text { of the plane, } \\
\text { hkl }\end{array}$ & $\begin{array}{c}\text { Interplanar } \\
\text { distances, } \\
\text { d, } \AA\end{array}$ & $\begin{array}{c}\text { Intensity: } \\
\text { as a peak in the } \\
\text { standard and as an } \\
\text { imp/sec in cement }\end{array}$ & $\begin{array}{l}\text { The symbol } \\
\text { of the plane, } \\
\text { hkl }\end{array}$ \\
\hline \multicolumn{6}{|c|}{ Alite $-54 \mathrm{CaO} \cdot 16 \mathrm{SiO}_{2} \cdot \mathrm{Al}_{2} \mathrm{O}_{3} \cdot \mathrm{MgO}$} \\
\hline $3,034 / 3,0329$ & medium/286 & 221 & $1,977 / 1,9794$ & rel.very weak./47 & 333 \\
\hline $2,9728 / 2,9708$ & very weak /70 & 402 & $1,934 / 1,9323$ & rel.very weak./99 & 22.10 \\
\hline $2,7761 / 2,7771$ & med.weak /365 & 009 & $1,7660 / 1,7644$ & medium weak /186 & 620 \\
\hline $2,748 / 2,7452$ & med.weak /310 & $\overline{4} 04$ & $1,6251 / 1,627$ & very weak /100 & $\overline{2} 2.13$ \\
\hline $2,608 / 2,6086$ & weak/260 & 405 & $1,5409 / 1,5408$ & rel.very weak./70 & 22.14 \\
\hline $2,323 / 2,3214$ & rel.very weak./74 & 407 & $1,4882 / 1,4885$ & very weak /100 & 049 \\
\hline $2,184 / 2,185$ & med.weak /160 & 408 & $1,4648 / 1,4611$ & rel.very weak./47 & 805 \\
\hline \multicolumn{3}{|c|}{ Belite $-\beta \cdot 2 \mathrm{CaO} \cdot \mathrm{SiO}_{2}$} & \multicolumn{3}{|c|}{ Celite $-4 \mathrm{CaO} \cdot \mathrm{Fe}_{2} \mathrm{O}_{3}$} \\
\hline $2,748 / 2,7452 *$ & weak/310 & 202 & $3,63 / 3,6597$ & very weak /40 & 031 \\
\hline $2,609 / 2,6086^{*}$ & weak/260 & 102 & $2,77 / 2,7771$ & weak/365 & 002 \\
\hline $2,434 / 2,4466$ & weak/50 & 112 & $2,63 / 2,651$ & very weak /125 & 141 \\
\hline $2,050 / 2,0547$ & weak/50 & 221 & $1,57 / 1,5754$ & weak/25 & 143 \\
\hline $1,820 / 1,8255$ & very weak /54 & 033 & $1,42 / 1,4238$ & rel.very weak./15 & 004 \\
\hline $1,718 / 1,7209$ & very weak /14 & 233 & & & \\
\hline
\end{tabular}

Radiographs of cement stone after 2, 7,14 and 28 day hardening are shown in Figs. 2-5, from which we can see that:

- on the radiograph (fig. 2) of cement stone hardened during two days, there are no hydrate phases of $\mathrm{Ca}(\mathrm{ON}) 2$ type, ettringite and calcium hydrosilicates - because of their small amount - less than 3\% and as a result of coincidence of lines of these phases with lines of initial minerals, especially with $\mathrm{C} 3 \mathrm{~S}$; however, the presence of hydrate phases in cement stone can be judged by the acquisition of its strength and increase the intensity of lines of $\mathrm{C} 3 \mathrm{~S}$ (by $5-25 \mathrm{imp} / \mathrm{sec}$ ) compared to the original ones due to coincidence of their lines; for example, the intensity of lines of C3S with interplane distances of $3.0329,2.7771,2.7452$ and $2.6086 \AA$ respectively increase by $10,18,25$ $\mathrm{imp} / \mathrm{sec}$; 


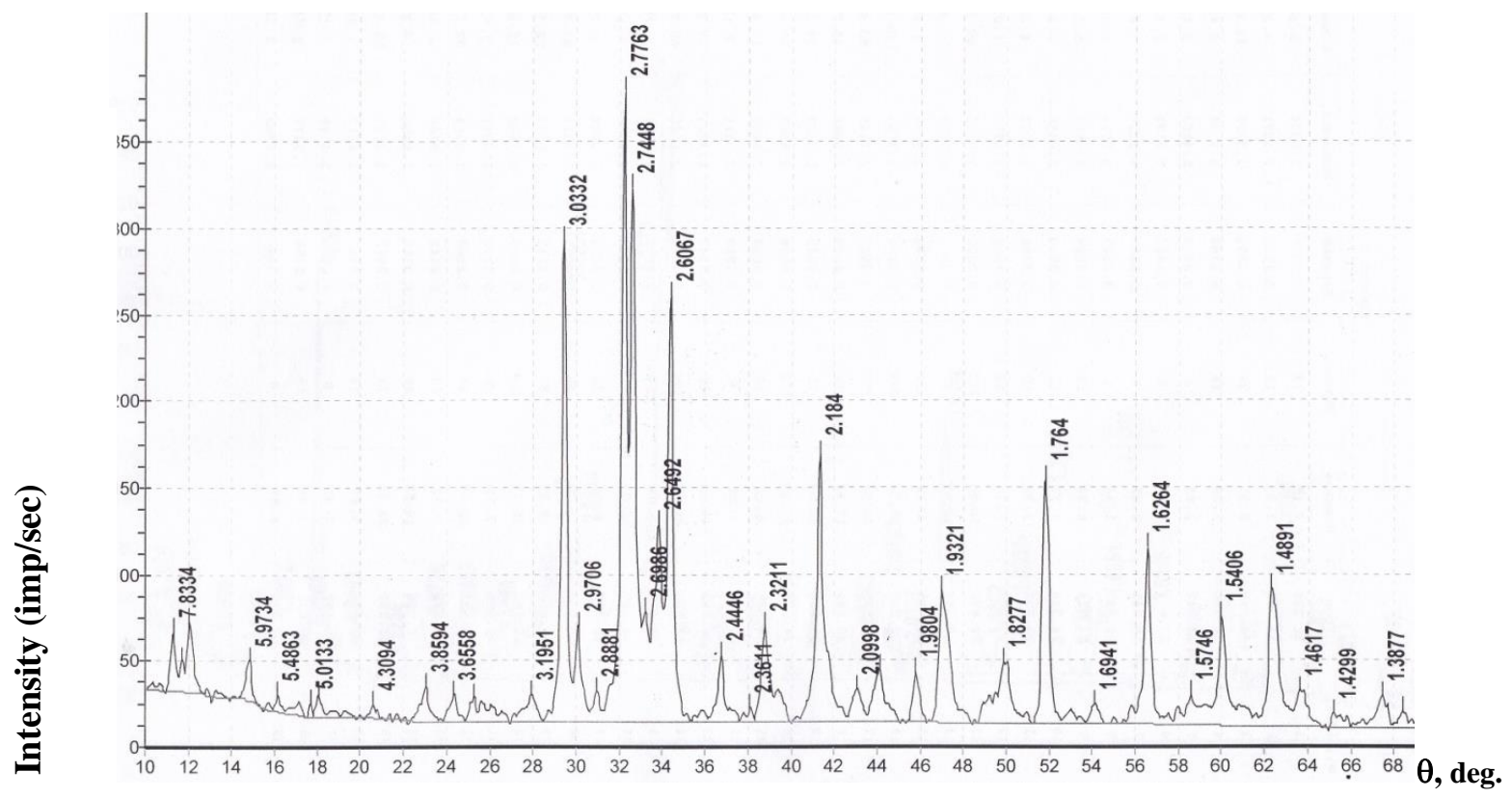

Figure 2 - Sample cement stone after 2 days of hardening

- In the cement stone in the seven-day age, the content of hydrate phases is noticeably increasing, as a result - on the radiograph (Fig. 3) appears analytical line $\mathrm{Ca}(\mathrm{OH}) 2(4,9012 \AA)$ with an intensity of $200 \mathrm{imp} / \mathrm{sec}$. Besides, intensity of lines of initial minerals essentially decreases; for example, intensity of line C3S at 2,7771 $\AA$ decreases to $280 \mathrm{imp} / \mathrm{sec}$; it is obvious that decrease in intensity of lines of initial clinker minerals would be even more, if lines of hydrate phases, in particular lime and ettringite, were not overlapped on them;

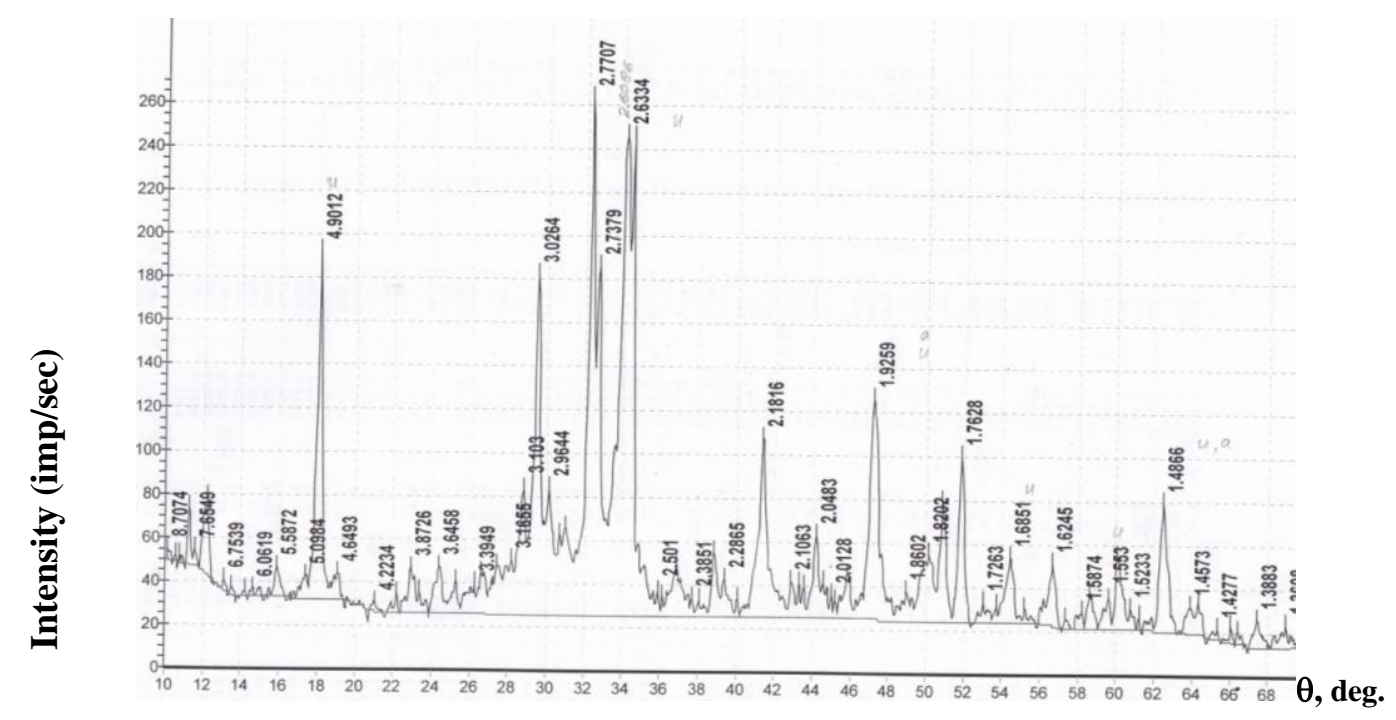

Figure 3 - Cement stone in 7 days

- radiograph (Fig.4) of 14-day cement stone «gives an abundant picture» as follows: 
- $\mathrm{Ca}(\mathrm{ON}) 2$ content in cement stone decreases and the value of the interplane distance of the analytical line $(4,9012 \AA \rightarrow 4,8987 \AA)$ decreases; the decrease of the interplane distance is caused by the introduction of Si4+ $(\mathrm{R}=0,42 \AA), A 13+(0,51 \AA)$ and $\mathrm{Fe} 3+(0,64 \AA)$ ions into the loose structure of $\mathrm{Ca}(\mathrm{ON}) 2$ where large tetrahedral voids are present;

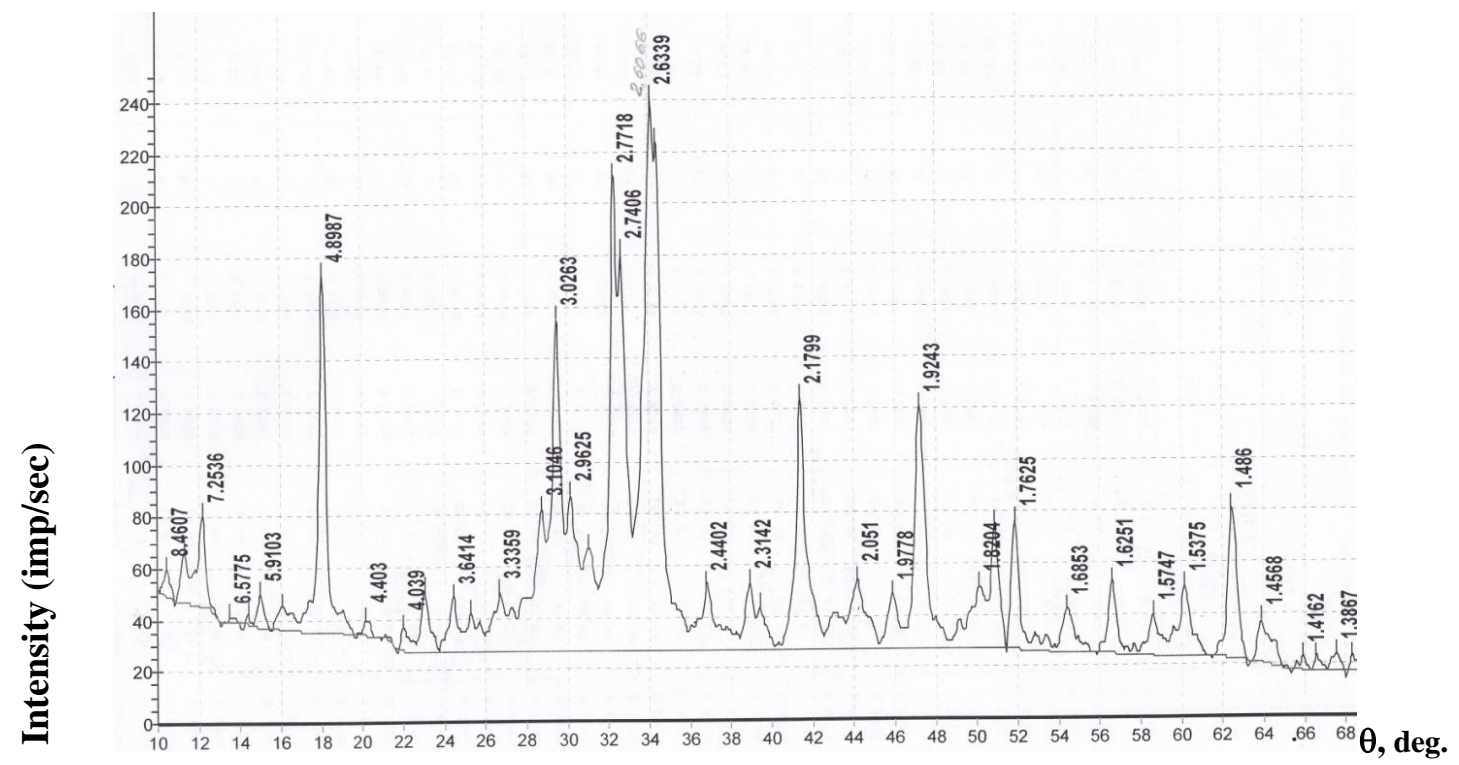

Figure 4 - Cement stone in 14 days

- the decrease in $\mathrm{Ca}(\mathrm{OH}) 2$ can be explained by the absorption of part of it by hydrated calcium silicate, which have a colloidal structure at that time;

- It is also possible that at this time the formation of a second-generation solid solution of $\mathrm{Ca}(\mathrm{ON}) 2$ as a result of isomorphism inside the portlandite base of individual tetrahedrons $(\mathrm{ON}) 4$ - to discrete $[\mathrm{SiO} 4] 4$ - by reaction is not excluded.:

$(\mathrm{OH})^{4-} \rightarrow\left[\mathrm{SiO}_{4}\right]^{4-}[3]$

- in addition, at the age of 14 the cement stone usually drops (or stops) its strength due to the transition of part of calcium aluminate trisulfate hydrate ( ettringite $-3 \mathrm{CaO}$ $\mathrm{Al} 2 \mathrm{O} 3-3 \mathrm{CaSO} 4)$.

$-31 \mathrm{H} 2 \mathrm{O}$ ) in calcium aluminate monosulfate hydrate (3CaO-Al2O3-CaSO4$12 \mathrm{H} 2 \mathrm{O})[4]$;

- In 28 days of age, the bending strength of cement stone is 7.4 MPa, compression strength is $54.1 \mathrm{MPa}$, and after steaming - $34.1 \mathrm{MPa}$, the degree of hydration reaches $22 \%$ (Table 3). These data are typical for cement PC 500 D0; here is how these properties of cement stone are reflected in the radiograph (Fig. 5):

-due to the formation and abundance of hydrate phases, the intensity of radiographic lines of source minerals decreases significantly and the indicators of interplane distances, as a rule, move towards greater and smaller numbers;

- reflection lines characteristic of trisulfohydroaluminate and calcium monosulfohydroaluminate $(3,8394 ; 3,619 ; 3,2063 \AA$, etc. $)$ clearly appear; 
- The intensity of the analytical line $\mathrm{Ca}(\mathrm{ON}) 2$ increases again $(\mathrm{J}=260 \mathrm{imp} / \mathrm{sec})$, besides its interplanar distance is further reduced $(\mathrm{d}=4,8559 \AA)$ as a result of Si4+, $\mathrm{Al} 3+$ and $\mathrm{Fe} 3+$ entering its structure.

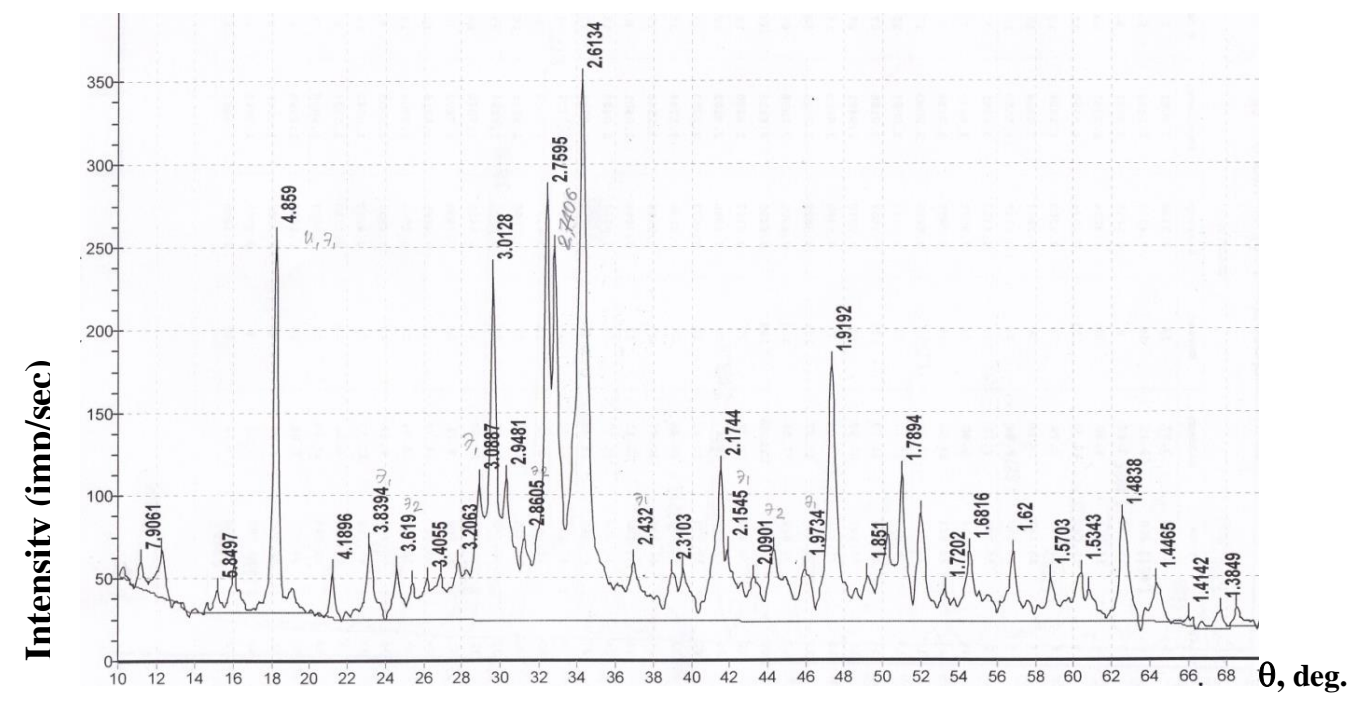

Figure 5 - PC 500 D0 - 28 days

\section{Conclusion}

1. Physico-mechanical properties of Portland cement, including setting time and strength, meet the grade PC 500 D0 and meet the technical requirements of GOST 10178-85. However, it has increased dispersibility and water consumption (NG $30 \%)$.

PC 500 D0 is made on the basis of clinker intended for cement production CEM I CC 42,5, therefore in terms of phase composition and content of $\mathrm{C}_{3} \mathrm{~A}$ and $\mathrm{SO}_{3}$ meets technical requirements of GOST 22266-2013.

2. It has been established that the main minerals of Portland cement clinker (C3S, $\beta-\mathrm{C} 2 \mathrm{~S}, \mathrm{C} 3 \mathrm{~A}$ and $\mathrm{C} 4 \mathrm{AF}$ ) in cement PC $500 \mathrm{D} 0$ are represented as solid solutions due to the presence of impurity ions in their structure. Therefore, the interplane distances are shifted towards large and small numbers as compared to the reference data. Peaks of solid solutions of alite, belite and ceite on the radiograph are fixed with increased intensity and are sharp, which indicates that the impurity ions that are part of the structure of these minerals, contribute to improving the pitch of their crystals.

3 . The radiograph of the cement stone of the 2-day hardening does not show hydrate phases, although it indirectly confirms that hydration processes in the hardening system take place; for example, the intensity of the peaks of the source minerals decreases and the samples have noticeable strength.

Radiographs of cement stone of 7, 14 and 28 daily hardening clearly show the lines of hydrate phases, especially the analytical line $\mathrm{Ca}(\mathrm{ON}) 2$ with an interplane distance of 4,9012-4,859 $\AA$, which can be used to trace the trend of changes in the phase composition of cement stone. 
Literature:

1. V.K. Klassen. Technology and optimization of cement production. - Belgorod: Belgorod State Technological University, 2012. - P. 308.

2. V.S. Gorshkov, V.V. Timashev, V.G. Saveliev. Methods of physical and mechanical analysis of binding materials. - Moscow: Higher School, 1981. - P. 335.

3. Physicochemical bases of cement stone structure formation/L.G. Shpynova, V.I. Chih, M.A. Sanitsky, H.S. Sobol, S.K. Melnik: Edited by L.G. Shpynova. - Lviv: Higher School, 1981. - P. 160.

4. Modern dry building mixes/T.K. Sultanbekov, G.Z. Shayakhmetov, K.T. Soltatbekov, Z.A. Yestemessov: Edited by Z.A. Yestemessov. - Almaty: TsELSIM, 2001. - P. 325.

Установлено, что физико-механические свойства портландчемента, включая сроки схватывания и прочность, соответствуют марке ПЦ 500 Д0 и отвечают техническим требованиям соответствующего стандарта. Однако обладают повыменной дисперсностью $и$ водопотребностью. Определено, что главные минераль портландиементного клинкера $\left(C_{3} S\right.$, $\beta$ - $C_{2} S, C_{3} A$ и $\left.C_{4} A F\right)$ в цементе представлены в виде твердых растворов в результате присутствия в их структуре примесных ионов. ньий камень.

Ключевые слова: иемент, физико-механические свойства, фазовый состав, цемент-

Портландиементтің физикальқ-механикальққ қุасиеттері, ұстап тұру мерзімі мен беріктігін қъоса алванда, ПЦ 500 Д0 маркасына сәйкес келетіні және тиісті стандарттың техникалық талаптарына жауап беретіні анықталды. Алайда, жовары дисперсиява және су тұтыну құжеттігіне ие. Цементтегі портландиементті клинкердің $\left(C_{3} S, \beta-C_{2} S, C_{3} A\right.$ және $\left.C_{4} A F\right)$ негізгі минералдары олардың құрылымында қ̧оспа иондарының болуы нәтижесінде құатты ерітінділер түрінде ұсынылатыны анықталды.

Түйін сөздер: цеммент, физикальқ-механикальққ қасиеттер, фазалық құрам, цемент тас. 